\title{
KONSEP KECERDASAN SOSIAL GOLEMAN \\ DALAM PERSPEKTIF ISLAM \\ (Sebuah Kajian Analisis Psikologi Islam)
}

\author{
Faisal Faliyandra \\ STAI Nurul Huda Kapongan \\ Email: faisalfaliyandra@gmail.com
}

\begin{abstract}
Abstrak
Daniel Goleman's social intelligence is one of Western psychology, which is certainly different from Islamic psychology. The main foundation of Islamic psychology is the Qur'an and the Hadith, which is different with western psychology which based on phenomelogy, so that the scope of western psychology only to the physical-biology, psychological dimensions and socioculture. From the analysis of several verses of the Qur'an, there are several indicators wrapped in two dimensions namely; feelings (1. Positif Thingking, 2. Affection, and 3. Sincere) and actions (1. Helping and 2. Gratitude). The five indicators as well as social intelligence developed by Goleman have a two-dimensional relationship between feelings (invisible) with actions which will be taken after having these feelings. As an example of the sincere indicator. Sincerity is an intention that cannot be expressed verbally, because its only Allah and the person who knows about the sincerity.
\end{abstract}

Keywords: social intelligence, Islamic perspective social intelligence, the psychology of Islam.

\section{Pendahuluan}

Agama Islam merupakan agama terakhir yang dianjurkan Allah SWT untuk manusia dimuka bumi yang dibawa Nabi Muhammad SWA dengan tujuan sebagai penyempurna agama-agama terdahulu. Dari penyempurnaan agama-agam terdahulu maka agama Islam memiliki ajaran yang sangat komperhensif. Secara garis besar ajaran Islam dapat dikelompokkan kedalam tiga kategori ; pertama Hablum Minallah yaitu tentang hubungan makhluk dengan Allah STW, kedua Hablum Minannas yaitu tentang hubungan baik antar manusia satu dengan manusia lainnya, ketiga Hablum Minal 'alam yaitu hubungan dengan alam sekitar.(Zaenal Asep Ausop, 2014) Sebagai umat Islam ketiga kategori tersebut haruslah diamalkan secara seimbang, walaupun pada hakekatnya Hablum Minannas dan Hablum Minal 'alam memiliki tujuan vertikal (Hablum Minallah) mendapat ridho Allah SWT. Akan tetapi ketika kita melihat realita yang sedang terjadi terdapat kesenjangan antara harapan dan hasil yang didapat dari ketiga konsep dasar ajaran 
Islam itu. Kesenjangan itu terlihat ketika dimensi sosial yang menegaskan tentang hubungan baik antar manusia satu dengan manusia (Hablum Minannas) lainnya menurun.

Kelunturan tersebut dapat dilihat dari berbagai macamnya konflik yang terjadi di berbagai daerah entah itu karena suku, agama, antar golongan. Tercatat beberapa perang suku berlandaskan karena perbedaan pendapat dan kedua belah pihak tidak ingin disalahkan.(Juditha Christiany, 2015) Bentrokan antar pelajar, Komnas PA mencatat pada tahun 2013 terdapat 255 kali tawuran terjadi di seluruh Indonesia. Angka-angka statistik tahun 2013 tersebut meningkat dari tahun 2012, secara rinci antara 147 kasus meningkat 255 kasus seperti yang dibertakan oleh tribunnews.com. Tidak dapat dipungkiri perpecah-belahan bangsa ini didalamnya terdapat umat Islam yang turut melakukannya.

Secara historis, ketika kita melihat perpecah-belahan dari sudut pandang islam sudah ada sejak zaman Nabi Mudahammad SWA. "Orang-orang Yahudi telah berpecah belah dalam tujuh puluh satu kelompok dan $\mathrm{Na-}$ shora berpecah belah menjadi tujuh puluh dua kelompok serta umat ini akan pecah menjadi tujuh puluh tiga kelompok". (HR al-Tirmidzi). Dari hadis diatas dapat dipahami bahwa perpecahan umat Islam pastilah terjadi, terlebih ketika pada akhir zaman saat ini. Nah dewasa ini yang menjadi perdebatan dikalangan akademisi dan pemerintahan bukan hanya konflik terjadi dimana-mana, tetapi saat ini lebih berfokus kepada ancaman Fanatisme dan Ektremisme. Faham Fanatis dan Ektremis dimana keyakinan yang dimiliki individu manusia yang terlalu kuat terhadap ajaran agama, politik, dan sebagainya yang sangat berbahaya bagi keutuhan semboyan Bhineka Tunggal Ika.(Karlina Supelli, 2011) Paham-paham fanatisme dewasa ini perlahan seperti firus yang menggerogoti ajaran hubungan baik dengan manusia (Hablum Minannas) dari bawah. Mereka selalu menjustifikasi kesalahan seseorang walaupun orang itu dari saudaranya sendiri (Islam) tentang pemahamannya terhadap agama yang mungkin benar dan mungkin juga salah. Pemutusan itu sendiri terkadang hanya bersifat objektif dan satu arah saja tanpa melihat berbagai sudut pandang yang lain yang 
tentunya juga harus objektif. Inilah kesalahan yang harus dibenahi agar pemutusan salah dan benar itu tidak menyakiti hati dan perasaan saudara seagama lainnya sehingga tidak berdampak kepada putusnya rasa persaudaraan antar umat Islam.

\section{Allah SWT berfirman} dalam Al-Quran surat Al-Hujurat ayat 12, artinya: "Hai orangorang yang berimana, jauhilah kebanyakan berprasangka, karena sesungguhnya sebagian tindakan berprasangka adalah dosa dan janganlah kamu mencari-cari kesalahan orang lain". Sejalan dengan ayat terse-but, Rasulullah Shalallahu'alaihi Wasallam juga bersabda tentang damapak buruknya mencari mencari kesalahan orang lain, yaitu; "Berhati-hatilah kalian dari tindakan berprasangka buruk karena prasangka buruk adalah sedusta-dusta ucapan. Janganlah kalian saling mencari berita kejelekan orang lain, saling memata-matai, saling mendeng$k i$, saling membelakangi, saling membenci. Jadilah kalian hambahamba Allah yang bersaudara". Kedua dasar tersebut dengan tegas melarang kita sebagai umat Islam tidak boleh mencaricari kesalahan saudara kita yang lainnya karena hal tersebut akan minimbulkan perpecahan antar sesama saudara.

Urgensi Hablum Minannas perlu dan harus kita sadari betul sebagai bangsa Indonesia yang besar dan majemuk yang didalamnya mayoritas Islam itu berkemang. Urgensi ini diperkuat ketika Allah SWT berfirman dalam Al-Quran surat Ali Imran ayat 103, artinya: "Dan berpegang teguhlah kamu sekalian dengan tali Allah dan janganlah kamu sekalian berpecah belah, dan ingatlah nikmat Allah atas kamu semua katika kamu bermusuh-musuhan maka Dia (Allah) menjinakkan antara hatihati kamu maka kamu menjadi bersaudara sedangkan kamu diatas tepi jurang api neraka, maka Allah mendamaikan antara hati kamu. Demikian Allah menjelaskan ayat-ayatnya agar kamu mendapat petunjuk". Lanjutnya Surat Al-Hujurat ayat 10 yang artinya: "Sesungguhnya orang-orang mukmin adalah bersaudara karena itu damaikanlah antara kedua saudaramu dan bertaqwalah kepada Allah supaya kamu mendapat nikmat"

Kedua Ayat diatas ini sangat jelas dan tegas memerintah kita untuk saling bersaudara dan tidak boleh saling bermusuhan. Sebagai makhluk ciptaan-Nya yang berada pada 
naungan sistem pemerintahan Ketuhanan Yang Maha Esa, kedua ayat diatas harus diaplikasikan dan diimplementasikan kepada sis-tem bermasyarakatan kita sebagai bangsa Indonesia. Sejalan dengan beberapa surat diatas, UUD 1945 juga sangat sangat jelas dan tegas mengamanatkan lapisan masya-rakat terutama pemerintah untuk melindungi segenap bangsa Indonesia dan tumpah darah Indonesia dengan tujuan membentuk kesejahteraan umum, mencerdaskan kehidupan bangsa, dan ikut melaksanakan ketertiban dunia yang berdasarkan kemerdekaan, perdamain abadi dan keadilan sosial.

Dari beberapa dasar diatas dapatlah kita tarik benang merah bahwa begitu pentingnya ajaran berhubungan baik dengan sesama manusia (Hablum Minannas) dengan tujuan akhir mengharapkan ridho Allah SWT (Hablum Minallah). Maka dari itu kita sebagai saudara yang terbungkus dalam satu Agama Islam haruslah berikhtiar bersama saling menginatkan, memahamkan, dan menciptakan hubungan baik dengan saudara kita yang seiman (Hablum Minannas). Maka dari itu haruslah ada ikhtiar nyata, terencana, dan sistematis. Ikhtiar nyata, terencana, dan sistematis hanya dapat dilakukan ketika konsep tersebut dapat diimplementasikan ke dalam sistem pendidikan. Karena pendidikan menjadi salah satu sarana yang efektif untuk menegakkan Hablum Minannas dengan tujuan utama Hablum Minallah dengan memasukkan karakter ini kepada setiap sikap dan tingkahlaku (kopetensi afektif) peserta didik disetiap jenjang pendidikan, terutama di sekolahsekolah yang berbasis keislaman. Ketika membicarakan tentang pendidikan, ilmu lain yang tidak dapat dilepas dari pendidikan ialah ilmu psikologi. Psikologi dalam ilmu pendidikan sangatlah penting bahkan menjadi bahan landasan untuk seorang guru memberikan pendekatan, metode, strategi,dan teknik untuk mentretmen peserta didik agar dapat meningkatkan segala potensinya (kognitif, afektif, dan psikomotor). Saat ini banyak referensi buku psikologi tapi tidak sepenuhnya dapat menjadi bahan rujukan dalam menyelesaikan pendidikan islam, karena media pemerolehan ilmunya tidak sejalan dengan dasar keislaman.(Abudin Nata) Maka dari itulah harus ada penemuan sebuah konsep ten-tang psikologi yang berlandaskan dan berdasarkan pada hukum-hukum 
Islam. Pada psikologi umum ilmu yang mempelajari hubungan baik dengan manusia lainnya disebut dengan kecerdasan sosial (social intellegences). Kecerdasan sosial merupakan ilmu psikologi yang pertama kali di paparkan oleh Thorndike, lalu dikembangkan oleh Gardner dan Goleman yang semua menyebutkan bahwa kecerdasan sosial ialah kemampuan manusia untuk menciptakan hubungan baik dengan manusia lainnya.

\section{Berdasarkan}

rasional diatas, maka tujuan tulisan ini untuk menemukan konsep kecerdasan sosial (social Intelligences) dalam konteks pendidikan islam yang dianalisis menggunakan psikologi pendidikan islam.

\section{Metodologi Penelitian}

Metode yang digunakan dalam penelitian ini adalah kualitatif deskriptif dengan mendapatkan berabagai sumber dari litelarur seperti artikel, media online, buku, dan lainnya. Dari sumber-sumber itu maka akan dikelolah atau dianalisis inti dari litelatur sedemikian rupa hingga mendapatkan suatu kesimpulan yang rasional tentang penelitian tersebut. Dengan langkahlangkah menganalisis dan menemukan dimensi dan indikator dari kecerdasan sosial yang dicetuskan oleh Daniel Goleman, menganalisis berbagai referensi psikologi Islam, lalu menganalisis konsep kecerdasan sosial di dalam Al-Quran dan berbagai referensi lainnya.

\section{Psikologi Islam}

Manusia dilahirkan ke muka bumi ini secara fitrah maka dibutuhkanlah usaha pendidikan sedari dini mungkin dari orang tua, walaupun cara dan metode pemberian pendidikan setiap orang tua berbeda-beda. Sama halnya ketika manusia sudah beranjak dewasa dibutuhkan juga cara-cara untuk mendidiknya oleh manusia yang lebih mampu. Dari urain ini jelas kiranya bahwa masalah pendidikan bukan masalah gampang seperti membalikkan telapak tangan, tetapi dibutuhkan proses yang sangat mendalam tentang pemahaman ilmu yang mendasar dan luas tentang permasalahanpermasalahan peserta didik agar proses pendidikan dapat berjalan sesuai tujuannya. Disinilah peran dan fungsi psikologi pendidikan merupakan ilmu yang harus dimiliki oleh pendidik agar dapat berupaya memecahkan permasalahan aktivitas individu dalam proses pendidikan. (Sumadi Surayabrata) Sehingga dapat 
dipahami bahwa psikologi pendidikan merupakan ilmu yang berusaha menjelaskan permasalahan peserta didik baik fisik maupun non fisik dilingkungan pendidikan. Sejalan dengan definisi tersebut tetapi beda dengan landasannya, dalam Islam juga mengenal apa yang dimaksut dengan psikologi pendidikan Islam.

Surat An-Nahl ayat 125,artinya: "Serulah (manusia) kepada jalan Tuhanmu dengan hikmah dan pelajaran yang baik dan bantalah mereka dengan cara yang baik. Sesungguhnya Tuhanmu Dialah yang lebih mengetahui tentang siapa yang tersesat dari jalan_nya dan Dialah yang lebih mengetahui orang-orang yang mendapat petunjuk". Lanjutnya Surat AlNahl ayat 78, artinya: " Dan Allah mengeluarkan kamu dari perut ibumu dalam keadaan tidak mengetahui sesuatu pun, dan Dia memberi kamu pendengaran, penglihatan, dan hati, agar kamu bersyukur".

Dari kedua ayat tersebut memberikan makna, pertama bahwa Islam mengakui bahwa pada hakekatnya manusia merupakan makhluk yang dapat terpengaruh dan berpengaruh, kedua Islam mengakui tentang adanya pendidikan yang dipe- roleh dari manusia yang lebih mampu ke dan dari manusia yang tidak mampu dalam konteks pengetahuannya, ketiga ajaran Islam juga mengakui bahwa dalam mendidik peserta didik harus menggunakan pendekatan, metode, dan strategi yang benar. Pengertian ini secara komperhensif menjelaskan arti tentang Psikologi Pendidikan Islam. Psikologi konstruktivisme sosial yang salah satunya dikembangkan oleh Vygotsky menjelaskan bahwa hakekatnya pengetahuan itu dibentuk akibat dari interaksi invidivu dengan sosialnya. Secara jelas pada teori konstruktivisme sosialnya Vygosky memaparkan fungsi dan tujuan orang orang dewasa (secara ilmunya) sebagai pembimbing pembentukan pengetahuannya, atau yang disebut dengan Zone of Proximal Development (ZPD). Ilmu psikologi konstruktivisme sosial ini sama seperti penafsiran Surat diatas yang menjelaskan bahwa hakikatnya manusia mendapat ilmu pengetahuan karena dari proses dipengaruhi dan terpengaruh dunia luar yang ditadai dengan pendengaran, pengli-hatan, dan hati.

Dalam

ajaran

Islam pengaruh lingkungan sosial (dimensi sosial) juga sangat diperhatikan. Pengaruh itu bukanya 
hanya tentang bagaimana seorang pendidik dalam lingkup dimensi sosial (orang yang lebih mampu ilmunya) dapat mempengaruhi peserta didik untuk memperoleh suatu ilmu, tetapi secara arti yang lebih luas ajaran Islam juga mengajarkan bahwa lingkungan geografi juga dapat berpengaruh dan mempengaruhi pengetahuan manusia, karena kekuasaan dan ilmu Allah SWT apapun yang ada dibumi dan langit. Surat Al-Mulk ayat 15, artinya: "Dia-laah yang Menjadikan bumi untuk kalian yang mudah dijelajahi, maka jelajailah disegala penjurunya dan makanlah sebagian rezeki-Nya. Dan hanya kepada-Nya-lah kamu (kembali setelah) dibangkitkan. Pada kalimat "Dia-laah yang Menjadikan bumi untuk kalian yang mudah dijelajah", mempunyai definsi Allah SWT menciptakan bumi seisinya (manusia dan alam) agar manusia dapat mengambil hikmah atau pejaran dari kekuasaan-Nya yang ada dilangit dan di bumi.

Sehingga dari pemaparan kajian diatas secara implisit mempunyai makna bahwa terdapat sudut pandang yang berbeda dari psikologi pendidikan umum dan psikologi pendidikan Islam. Ketika kita menilik psikologi secara umum semua landasan pembentukannya dari beberapa ahli psikologi barat. Seperti contoh Jean Piaget seorang filsuf sekaligus psikolog berasal dari Swis yang terkenal dengan teori perkembangan pengetahuan dan konsep teori konstruktivisme. Samapai saat ini disadari atau tidak disadari terori perkembangan pengetahuan dari Piaget ini masih digunakan oleh para akademisi, entah itu dari akademisi pendidikan secara umum atau pendidikan Islam. Piaget menemukan teori ini berasal ketika bertahun-tahun meneliti tentang anaknya sendiri sedari kecil hingga tumbuh dan berkembang menjadi dewasa. (B.R. Hergenhahn dan Matthew H. Olson, 2008) Lanjutnya Edward Lee Thorndike yang menggunakan hewan pengerat sebaagai bahan penelitiannya, Ivab Petrovich Pavlov yang memperkenalkan tentang stimulus yang dapat dikondisikan, Cralk Leornard Hull yang terkenal dengan tes bakatnya. Semua pakar atau ahli psikologi barat memfokuskan tentang makhluk hidup sebagai dasar pencarian ilmunya. Nata (2018:2-3) menjelaskan pendapat ini memiliki dasar karena bahwa psikologi barat dasar ilmunya diambil dari permasalahan - permasalahan manusia secara umum 
(fenomelogi) sehingga tercipta teori psikologi barat yang berparadigma bahwa manusia sebagai subjek dan objek sebagai pencarian ilmunya. Inilah yang perlu diperhatikan bersama, bahwa secara dasarnya psikologi umum merupakan ilmu yang berkembang dengan hanya mempelajari permasalahan-permasalahan manusia dengan berbagai metode ilmiahnya. Berbeda dengan apa yang didasari pemerolehan ilmu psikologi Islam.

Prof. Zakiah Daradjat menjelaskan bahwa Psikologi Islam memiliki ruang lingkup sendiri yang membedakan dengan psikologi barat.(Ema Yudiani, 2013) Perbedaan itu terlihat ketika fokus kajian psikologi barat hanya mengkaji fenomelogi, sehingga ruang lingkup psikologi barat terbatas hanya berdasar kepada fisikbiologi, dimensi kejiwaan dan sosiokultur.(Abudin Nata) Maka dari itu ketika ingin mengkaji lebih mendalam tentang psikologi Islam yang harus diperhatikan ialah ruang lingkupnya yang tidak sama dengan psikologi barat. Ruang lingkup psikologi islam bukan hanya memfokuskan keilmuannya tentang permasalahan manusia atau tingkah laku manusia terhadap manusia lainnya (Hablum Minannas), tetapi mempelajari tentang bagaimana permasalahan manusia bertingkah laku terhadap Allah SWT (Hablum Minallah). Jadi fokus kajian psikologi Islam meambahkan dimensi kerohanian, dimensi spritual, sebuah analisis yang berlum terjamah dalam psikologi barat.

\section{Kecerdasan Sosial}

Definisi cerdas dalam Kamus Besar Bahasa Indonesia adalah kesempurnaan perkembagan akal budinya. Maka ketika kita membicarakan kecerdasan ada kaitannya dengan akal manusia. Akal merupakan pemerian paling berharga yang dibeikan Allah hanya kepada manuia, karena dengan akallah yang membedakan manusia dengan makhluk lainnya (hewan dan tumbuhan). Seperti contoh he-an hanya mengandalkan nalurinya saja, ketika lapar hewan itu makan dan minum tanpa melihat apakah makanan itu kotor, bernutrisi, bermanfaat tidak bagi tubuh dan orang sekitarnya. Berbeda dengan manusia, ketika manusia kelaparan mereka pasti mecari makanan yang bernutrisi, bermanfaat bagi tubuhnya bahan Islam menganjurkan mencari makanan dengan jalan yang halal agar terjauh dari prilaku 
yang menyimpang dari aturan agama. Penjelasan ini memliki dasar kuat ketika Al-Baqaah:168 yang menjelaskan "Hai sekalian manusia, makanlah yang halal lagi baik dari apa yang terbaik dibumi, dan janganlah kamu mengikuti langkah-langkah syaitan; karena sesungguhnya syaitan itu musuh yang nyata bagimu. Dasar ini membuktikan bahwa penggunaan akal budi sangat penting ketika manusia mencari sumber kehidupan seperti makanan dan minuman.

Bukan hanya dalam ajaran Islam saja yang mementingkan manusia menggunakan akal budi dalam memenuhi segala kebutuan hidupnya, bahkan dalam daar sistem pemerintahan Indoneia yaitu Undang-Undang Dasar 1945 akal budi sangat diperhaikan. Pentingnya akal ini dapat juga dilihat ketika UUD 1945 pada alinea 4 mengamanatkan kepada semua komponen masakat Indonesia dan khususnya pemerintah untuk mencerdaskan kehidupan bangsa Indonesia. Dalam kalimat mencerdaskan kehipan bangsa disanalah secera eksplisit masyarakat Indonesia harus menggunakan akalbudinya atau kecerdasannya untuk memiah mana yang bermanfaat dana yang tidak bermanfaat, terlebih ketika manusia berproses ke alam lingkungan sosial. Manusia harus menggunakan kecerdasanya agar dapat berhubungan baik dengan manusia, seperti contoh hormat kepada orang yang lebih tua, menghargai pendapat orang lain, suka menolong. Ketika individu dalam lingkungan sosial menggunakan kecerdasannya maka dapat dipastikan individu dapat diterima oleh lingkungan sekitarnya. Contoh ketika Rosulullah SAW menggunakan kecerdasannya menyatukan umat Islam dan Yahudi dalam sebuah konstitusi tertulis pertama yaitu Piagam Madinah. Ini merupakan contoh nyata bagaimana pentingnya sebuah kecerdasan harus digunakan dalam berbagai macam proses kehidupan atau dimensi sosial. Dalam ilmu psikologi umumnya kecerdasan yang digunakan oleh Rosulullah dalam menangani permasalahan yang terjadi di Madinah tersebut ialah kecerdasan sosial.

Kecerdasan sosial merupakan ilmu psikologi yang mempelajari hubungan baik dengan manusia. Konsep kecerdasan social secara umum memberikan penjelasan bagaimana individu manusia dapat mengelolah emosinya agar mampu bertindak atau berinteraksi positif dengan sesama individu atau kelompok manusia. Jika kita mencari konsep 
kecerdasan sosial sebenarnya konsep ini sudah di paparkan oleh pakar psikologi Amerika yaitu Edward Thorndike pada tahun 1920-an. Thorndike mengemukakan konsepnya tentang tentang kecerdasan sosial yang memiliki arti tentang kemampuan hubungan baik antar manusia. Pada masa itu juga telah lahir tentang konsep IQ sebagai sebuah tes kongitif yang bertujuan untuk mengukur seberapa besar kemampuan manusia dilihat dari sudut pandang kognitifnya. Kemunculan kecerdasan sosial bersamaan dengan ilmu psikometrika membentuk konsep kepada tokohtohoh psikologi di zaman itu bahwa kecerdasan social hanyalah suatu pengetahuan individu manusia menghadapi individu atau kelompok pada lingkungan sosialnya, sehingga membentuk pemikiran bahwa kecerdasan social ini hanya dilihat dari ranah kognitif.

Pada zaman ini konsep kecerdasan sosial lebih diperhatikan oleh pakar-pakar psikologi karena memandang kecerdasan sosial sebagai ilmu yang bukan hanya dilihat dari segi kognitifnya saja, tetapi juga dapat dipandang dari segi afektifnya (sikap). Terdapat beberapa tokoh yang konsep kecerdasan sosialnya sampai saat ini masih diaplikasikan dan diperhatikan oleh pakar-pakar pendidikan, seperti contoh Howard Gagner yang juga menemukan konsep tentang kecerdasan sosial dalam bukunya berjudul Frames of Mind:Teori Multiple Intelegences. Gagner pada bukunya yang menjelaskan tentang delapan kecerdasan yang dimiliki oleh manusia, memaparkan konsep tentan kecerdasan sosial atau yang disebut kecerdasan interpersonal sebagai kemampuan untuk membina hubungan yang efektif dengan orang lain. (Thomas R. Hoeer) Daniel Goleman dalam bukunya yang berjudul Social Intellegence menjelaskan bahwa kecerdasan sosial adalah sebuah kemampuan manusia yang menggabungkan perasaan (emosi) dan tindakan sehingga membentuk interaksi positif dengan manusi lainnya.

Dari kedua konsep diatas, konsep kecerdasan sosial yang disuguhkan oleh Gagner tentang kecerdasan interpersonalnya ini sesungguhnya tidak dapat membedakan lebih sepesifik ten-tang kecerdasan sosial sebagai suatu kemampuan kognitif verbal manusia menghadapi pemecahan masalah lingkungan sosialnya. Konsep kecerdasan sosial yang membedakannya dari kemam- 
puan kognitif individu manusia ini di paparkan oleh pakar Psikologi Daniel Goleman. Goleman secara tegas memaparkan tentang konsep kecerdasan sosial yang keluar dari ranah kognitif ke nonkognitif yang ditunjukkannya dari dua dimensi besar yaitu, tentang kesadaran diri dan manajeman diri. Pemaparan dimensi tentang kecerdasan sosial Goleman dapat dilihat sebagai berikut;

Tabel : Dimensi dan Indikator Kecerdasan Sosial

\begin{tabular}{|c|c|c|}
\hline No & Dimensi & Indikator \\
\hline \multirow[t]{4}{*}{1} & \multirow[t]{4}{*}{ Kesadara Diri } & Empati \\
\hline & & Penyelarasan \\
\hline & & Empati \\
\hline & & Pengertian sosial \\
\hline \multirow[t]{4}{*}{2} & \multirow[t]{4}{*}{ Manajemen Diri } & Mensinkroni \\
\hline & & Mempresentasikan diri \\
\hline & & Mempengaruhi \\
\hline & & Kepedulian \\
\hline
\end{tabular}

Pada tabel diatas menunjukkan kedua dimensi yaitu kesadaran diri dan manajemen diri tidak dapat dipisahkan atau saling berhubungan. Kesadaran diri ialah apa yang kita rasakan tentang orang lain, secara psikologis perasaan itu merupakan emosi kasat mata yang dimiliki manusia. Manajemen diri adalah apa yang akan kita lakukan ketika memiliki perasaan terhadap orang lain, secara jelas ini merupakan tindakan yang dapat dilihat oleh orang lain. Seperti contoh ketika kita memiliki perasaan (empati) terhadap orang lain, maka secara secara otomatis kita akan memiliki menolong orang atau bisa disebut sikap peduli. Contoh lainnya tentang pengertian sosial yang merupakan pengetahuan kita bagaimana ketika berada di lingkungan sosial terkait aturan dan normanya, maka secara otomatis kita dapat menampilkan diri secara efektif di lingkungan sosial.

Kemampuan berhubungan baik seperti yang diatas sangat perlu dimiliki oleh setiap individu karena pasalnya dewasa ini maraknya para remaja yang 
memiliki sikap anti-sosial. Untuk menghilangkan sikap anti-sosial dapat dilaksanakan manakala terciptanya lingkungan yang mendukung perkembangan kecerdasan sosial, karena pengaruh sosial dan budaya memiliki dampak yang sangat signifikan dalam pembentukan sikap antisosial.(Kartini Kartono)

\section{Konsep Kecerdasan Sosial Dalam Perspektif Agama Islam}

Berhubungan baik dengan sesama manusia atau yang disebut Hablum Minannas merupakan salah satu dari dua kerangka besar dalam ajaran agama Islam yang implementasinya tidak keluar dari hakikatnya untuk mendapat ridho Allah Hablum Minallah. Dalam realitanya terakadang kedua karangka tersebut tidak berjalan beriringan. Dalam satu sisi terdapat manusia sangat menjaga hubungan baik dengan Tuhan, tetapi disisi lain manusia tersebut tidak dapat menjalin hubungan baik dengan sesama manusia. Atau pun sebaliknya yang terjadi, ketika manusia sangat bisa berhubungan baik dengan manusia lainnya tetapi tidak dapat menjalin hubungan dengan Tuhannya.
Untuk mengintegrasikan kedua konsep Hablum Minallah dan Hablum Minannas tersebut, kita sebagai umat Islam harus mencontoh Nabi Mudahammad. Allah dalam surat Al-Qalam 68:4 "Dan sesungguhnya, kamu (Muhammad) benar-benar berbudi pekerti yang agung". Rosulullah merupakan contoh tauladan terbaik yang dapat kita tiru karena ketika menjadi tauladan dimensi sosial Rosulullah tidak pernah melepaskan hubungan baik dengan Allah. Ingat ketika Rasululluh sedang bercengkrama disebuah masjid dengan para sahabatnya, lalu melihat seorang Badui membuang air kecil di sudut masjid. Rosulullah tidak membentak atau malah mengatakan kata-kata kasar seorang Badui tersebut, malah mempersilahkan untuk menuntaskan membuang air kecilnya. Setelah orang Badui tersebut tuntas membuang air kecil barulah Rosulullah menjelaskan dengan kesosialan yang tinggi bagaimana etika memperlakukan masjid dengan benar. Cerita tersebut memberikan makna bahwa dalam ajaran islam menjaga hubungan baik dengan manusia lainnya sangatlah dianjurkan. Pernyataan ini sejalan seperti kelanjutan cerita Badui yang mana dalan cerita tersebut 
Jurnal Inteligensia, Volume 7, No. 2, September 2019

Rosulullah menjelaskan " $F a$ innama bu'itstum muyassiriin wa lam tub'atsu mu'assirin yang artinya sesungguhnya kalian diutus untuk memberi kemudahan dan tidak diutus untuk membuat kesulitan," Maka sesungguhnya kita sebagai manusia harus memiliki sikap dan perilkau seperti berbaik sangaka terhadap orang lain, tolong- menolong, mendengarkan keluhan orang lain, merasakan kesusahan orang lain yang kesemua itu merupakan kemampuan berhubungan baik dengan manusia lainnya.

Berfokus pada kalimat berhubungan baik dengan manusia, Aristoteles menjelaskan manusia ditakdirkan untuk hidup bermasyarakat sehingga muncullah manusia sebagai makhluk sosial, yang artinya bahwa manusia tidak bisa hidup sendiri harus ada interaksi antar manusia lainnya. Dalam ilmu psikologi yang sama maknanya dengan hubungan baik manusia dengan manusia lainnya dapat kita lihat pada kecerdasan sosial (social Intellegences). Thonrdike sebagai pelopor konsep kecer-dasan sosial yang digunakan oleh berbagai tokoh psikologi lainnya menjelaskan kecerdasan sosail ialah sikap bijak manusia dalam melakukan hubungan dengan orang lain. Gagner mejelaskan tentang kecerdasan sosial sebagai salah satu dari kedelapan kecerdasan yang dimiliki manusia yang disebut kecerdasan interpersonal. Konsep kecerdasan sosial juga ditemukan dan dikembangkan oleh Goleman. Dari ketiga pakar psikologi yang menjelaskan tentang indikator dan proses kecerdasan sosial yang cukup lengkap dan jelas ialah Goleman. Dalam bukunya yang berjudul Social Intelligences, Goleman menjelaskan proses mendasar bagaimana kecerdasan sosial bekerja pada manusia. Proses tersebut dijelaskan dalam dua kategori besar, pertama tentang bagaimana individu manusia merasakan keadaan sosial disekitarnya, kedua dari apa yang dirasakan barulah individu tersebut bertindak. Maka ketika individu manusia melakukan hubungan atau interaksi positif dengan individu lainnya pertama yang mereka lakukan adalah merasakan emosi terhadap lawannya, ketika emosi tersebut singkron dengan apa yang individu itu rasakan lanjutnya akan terjalin sikap dan tingkahlaku yang baik kepada lawannya. Dari penjelasan tersebut maka individu haruslah memiliki beberapa indikator emosi positif (empati, empatik, selaras, pe- 
ngertian sosial) dan tingkahlaku baik (sinkroni, presentasi, mempengaruhi, kepedulian).

Berfokus kembali kepada psikologi islam yang sangat berbeda sekali dengan psikologi pada umummnya. Perbedaan itu dapat dilihat dari dasar penemuan psikologi barat yang fokus penemuan keilmuannya bertumpu kepada manusia sebagai dasar penemuan keilmuannya, psikologi Islam mempunyai dasar tersendiri sebagai sandaran keilmuan atau ajarannya. Sama seperti penjelasan diatas, Prof. Zakiah Daradjat memaparkan bahwa ruang lingkup Psikologi Islam membahas tentang dimensi kejiwaan, fisik-biologis, sosiokultur, kerohanian, dan dimensi spritual.(Ema Yudiani) Sehingga psikologi barat sepenuhnya tidak dapat memberi andil terhadap permasalahan-permasalahan pendidikan Islam. Untuk membuktikannya, ketika kita mau menganalisis indikator kecerdasan sosial yang dikembangkan oleh Goleman. Dari beberapa analisis diatas terdapat beberapa indikator yang sangat jelas bahwa fokus kecerdasan sosial hanya kepada manusia sebagai pusat keilmuannya (antroposentrisme).

Dari pemaparan penjelasan diatas dapat ditarik benang merah bahwa psikologi Islam memiliki ruang lingku yang lebih komperhensif dan fundamental yang bukan hanya menjelaskan tentang fisik-biologi, dimensi kejiwaan dan sosiokultur (Hablum Minannas), tetapi juga menjelaskan tentang kerohanian, dimensi spritual (Hablum Minallah). Inilah yang dasar pengembangan kecerdasaan sosial islam yang saya maksut. Kecerdasan sosial Islam bukan hanya menjelaskan tentang bagaimana kemampuan manusia berhubungan dengan manusia lainnya, tetapi lebih fundamental lagi bahwa dari berhubungan baik dengan orang lain bertujuan untuk mencari Ridho Allah SWT. Ketika manusia sebagai ciptaan Allah memiliki kecerdasan sosial tinggi, maka segala perbuatan baiknya kepada orang lain diniatkan untuk mencari ridhoNya sehingga manusia tidak akan mencari imbalan atau respon atas tindakan baiknya kepada manusia lainnya. Ketika manusia berbuat baik kepada manusia lain karena ingin mendapat imbalan, ketika imbalan itu tidak sepadan dengan apa yang mereka harapkan malah bukan hubungan baik yang didapatkan malah sebaliknya yaitu akan saling bermusuhan. Bermusuhan ini akan membalikkan hakikat 
konsep dari kecerdasan sosial itu sendiri.

Untuk menentukan hubungan baik antar manusia dalam konteks ajaran Islam, ada baiknya kita kembali ke sumber Islam itu sendiri yaitu Al-Quran dan Sunnah Nabi Muhammad SAW. Yang dimaksut kembali ke Al-Quran dan Sunnah ialah baik dan buruk hubungan manusia kepada manusia lainnya bukan dari sumber manusia itu sendiri (antroposentrisme), tetapi baik dan buruh hubungan manusia harus berlandaskan dari Al-Quran dan Hadist. Allah berfirman dalam Al-Baqarah:216 "Boleh jadi, kamu membenci sesuatu, padahal ia amat baik bagimu, dan boleh jadi kamu menyukai sesuatu, padahal ia amat buruk bagimu. Allah yang paling mengetahui, sedangkan kamu tidak mengetahui". Hal ini diharuskan karenena ketika kita mengukur hubungan baik dan buruk dari sudut pandang manusia maka akan terjadi perdebatan yang tidak akan habishabisnya karena belum tentu apa yang dikatakan salah satu manusia baik, belum tentu dapat diterima manusia dalam lingkungan lainnya.

\section{Hubungan Baik Antar Manusia dalam Islam}

Islam merupakan agama yang terakhir dan juga sebagai penyempurna agama terdahulu yang dibawa oleh Nabi Muhammad. Maka dari kalimat penyempurna tersebut memiliki makna bahwa agama Islam memiliki hukum-hukum yang lengkap dan terbaru. Kelengkapan hukum dan ajaran Islam dapat dipahami ketika kita seabagai makhluk ciptaan Allah SWT memahami seluruh isi bacaan Al-Quran, yang mana semua isi yang terkandung didalamnya merupakan wahyu diturunkan kepada Rosulullah.

Kebenaran Al-Quran merupakan kitap suci agama Islam yang didalamnya terdapat segala macam sumber utama ajaran tidak dapat diragukan lagi. Dengan demikian ketika AlQuran merupakan sumber ajaran Islam yang didalamnya terdapat berbagai macam ilmu-ilmu maka semua umat Islam wajib mengetahui dan memahami isi yang terdapat pada Al-Quran. Isi yang terkandung pada Al-Quran itu mencakup keseluruhan aspek tentang kehidupan manusia dimuka bumi seperti aqidah, syariah, ahklak, dan ilmu pengetahuan. (Marzuki) Dari kesemua aspek tersebut terbungkus kedalam dua konsep 
besar yaitu Hablum Minallah dan Hablum Minannas.

Hablum Minallah adalah konsep bagaimana manusia berhubungan dengan sang maha pencipta Allah dengan mengikuti segala perintahnya dan menjauhi larangannya, sedangkan Hablum Minannas adalah konsep dimana individu manusia menjaga hubungan baik dengan individu atau kelompok manusia lainnya. Semua itu mencakup dimensi religius dan sosial yang dimana ketika kedua dimensi tersebut dapat di aplikasikan dan diimplementasikan dalam kehidupan bermasyarakat akan membentuk manusia yang berimana. Terlebih pada saat ini sudah terbukti bahwa dimensi sosial (Hablum Minannas) perlahan mulai meluntur. Kelunturan tersebut menjadi sangat urgen harus segera diperbaiki ketika Al-Quran sangat jelas memerintahkan kepada umat Islam untuk selalu menjaga hubungan baik dengan manusia lainnya tanpa menyingkirkan hubungan dengan Allah. Untuk itulah sumbersumber agama yang ada pada Al-Quran dan hadist harus dan perlu diingat, dipahami, dianalisis secara menyeluruh sehingga setiap individu dan kelompok dapat mengaplikasikannya dengan benar.

Bertumpu dari rasional sudut pandang penejelasan diatas, dibawah ini terdapat beberapa pembahasan di dalam Al-Quran yang menjelaskan tentang hubungan baik dengan manusia tanpa memalingkan hakikat untuk mencari ridho Allah.

\begin{tabular}{|c|c|c|c|}
\hline No & & Indikator & Sumber \\
\hline \multirow[t]{3}{*}{1} & \multirow[t]{3}{*}{ Perasaan } & Kasih sayang & $\begin{array}{l}\text { Ali Imran 14, An Nisa 1, } \\
\text { Ar Ruum 21, Adz, Al- } \\
\text { Mumthahanah 7, Maryam } \\
\text { 96, At Taubah 128, }\end{array}$ \\
\hline & & Ikhlas & $\begin{array}{l}\text { Al-A'raf 29, Shad 82, Az- } \\
\text { Zumar 2, Az-Zumar 11, } \\
\text { Al-Hijr 39, Al-Mu'min 14 } \\
\text { \& 65, Al-Bayyinah 5, An- } \\
\text { Nahl } 90 .\end{array}$ \\
\hline & & Berbaik sangka & Al-Hujurat 12. \\
\hline
\end{tabular}


Jurnal Inteligensia, Volume 7, No. 2, September 2019

\begin{tabular}{|l|l|l|l|}
\hline 2 & Tindakan & Menolong & Al-Maidah 2. \\
\cline { 3 - 4 } & Silaturahmi & $\begin{array}{l}\text { An-Nisa 1, Muhammad } \\
22 .\end{array}$ \\
\hline
\end{tabular}

Tabel diatas merupakan beberapa indikator hubungan baik dengan manusia yang didapatkan dalam Al-Quran. Keempat indikator tersebut seperti halnya kecerdasan sosial yang dikembangkan oleh Goleman mempunyai hubungan dua dimensi besar, antara perasaan (kasat mata) dengan tindakan yang akan dilakukan setelah mempunyai perasaan tersebut. Seperti contoh pada indikator ikhlas. Ikhlas merupakan niatan yang tidak dapat di ungkapkan secara verbal, karena yang dapat mengetahui orang itu ihhlas atau tidaknya hanya Allah dan manusia itu sendiri.

\section{Menolong}

Dalam Al-Quran terdapat beberapa aspek yang memerintahkan kita sebagai umat muslim untuk saling tolong menolong, seperti yang dijelaskan pada Surat Al-Maidah (5:2), AlBaqarah(2:177):

"Dan tolong-menolonglah kamu dalam (mengerjakan) kebajikan dan takwa, dan jangan tolong menolong dalam berbuat dosa dan pelanggaran. Dan bertakwalah kamu kepada Allah, sesungguhnya Allah amat berat siksa-Nya"

"Bukanlah menghadapkan wajahmu ke arah timur dan barat itu suatu kebajikan, akan tetapi sesungguhnya kebajikan itu ialah beriman kepada Allah, hari kemudian, malaikat-malai-kat, kitab-kitab, nabi-nabi dan memberikan harta yang dicintainya kepada kerabatnya, anakanak yatim, orang-orang miskin, musafir (yang memerlukan pertolongan) dan orangorang yang meminta-minta; dan (memerdekakan) hamba sahaya, mendirikan shalat, dan menunaikan zakat; dan orang-orang yang menepati janjinya apabila ia berjanji, dan orang-orang yang sabar dalam kesempitan, penderitaan dan dalam peperangan. Mereka itulah orang-orang yang benar (imannya); dan mereka itulah orang-orang yang bertakwa."

Menolong merupakan tindakan yang di wajibkan oleh Allah kepada semua umat muslim sejak masa Rosulullah. Menolong ialah membatu untuk meringankan beban orang lain. Pada 
dasarnya menolong bukan merupakan suatu tindakan meringankan beban dengan memberi bantuan materi sajam tetapi juga pikiran, dan tenaga. Orang yang memiliki ilmu menolong dengan ilmunya seperti contoh guru. Orang sehat membantu orang yang sedang sakit dengan cara menjenguknya dan mendo'akannya.

Ketika kita memberikan pertolongan kepada seseorang, secara psikologis bukan hanya berdampak kepada orang lain tetapi juga berdampak kepada diri kita sendiri. Dampak itu dapat kita rasakan seperti mengurangi depresi. Perasaan bahwa kita dapat menolong seseorang merupakan perasaan yang sangat luar biasa. Dari kita menolong seseorang seakan hidup dapat berguna bagi orang lain. Secara tidak sadar membuat hidup kita merasa optimis, bahwa kita juga bisa melakukan yang orang lain lakukan. Dampak lain bisa berupa ketenangan hati. Menolong orang yang lebih membutuhkan membuat kita sadar bahwa masih banyak yang lebih membutuhkan dari pada kita. Kesadaran akan tertindasnya orang lain daripada kita akan berdampak pada prasangka positif terhadap-Nya, maka dari itu semua akan muncul ketenangan hati.

\section{Ikhlas}

Dalam Al-Quran terdapat beberapa aspek yang memerintahkan kita sebagai umat muslim untuk ikhlas dalam melakukan apapun, seperti yang dijelaskan pada Surat Shad 8283, Az-Zumar 11, Al-Mu'min 65:

"Iblis menjawab:"Demi kekuasaan Engkau aku akan menyesatkan mereka semuanya, kecuali hamba-hamba-Mu yang ikhlas di antara mereka"

"Katakanlah: "Sesungguhnya aku diperintahkan supaya menyembah Allah dengan mengikhlaskan ketaatan kepadaNya dalam (menjalankan) agama"

"Dialah Yang hidup kekal, tiada Tuhan (yang berhak disembah) melainkan Dia: Maka sembahlah Dia dengan mengikhlaskan ibadah kepadaNya. Segala puji bagi Tuhan semesta alam"

Ikhlas merupakan kalimat yang mudah diucapkan secara verbal tetapi pengamlikasiannya tidaklah mudah. Pengaplikasiannya hanya dapat dilaksanakan ketika surat Al-An'am (162) menjelaskan "Sesungguhnya shalatku, ibadahku, hidup dan matiku hanyalah untuk Allah, 
Jurnal Inteligensia, Volume 7, No. 2, September 2019

Tuhan semesta alam". Maka manusia yang ikhlas adalah mereka yang melakukan segala perbuatannya karena Allah semata, tanpa mengharap balasan dari manusia lainnya. Dalam Al-Quran terdapat berapa contoh tentang sikap Nabi Luth kepada kaumnya, Surat As-Syu'ara (26:164) "Dan aku tidak meminta imbalan kepadamu atas ajakan itu, imbalanku hanyalah dari Tuhan seluruh alam". Sehingga dari perkataannya, Nabi Luth akan diusir karena mengajak kaumnya untuk tidak melakukan hubungan antar sesama jenis (laki-laki dengan laki-laki). Nabi Syu'aib yang memerintah kaumnya untuk tidak merugikan sesama manusia dengan menyempurnakan tarakan. Dalam surat As-Syu'ara (26:180) ajakan Nabi Syu'aib itu dilandaskan karena keihlasan untuk mendapat ridho Allah "Dan aku tidak meminta imbalan kepadamu atas ajakan itu; imbalanku hanyalah dari Tuhan seluruh alam".

Pada kultur jawa kalimat ikhlas memiliki bahasa yang berbeda-beda seperti nerimo, kanthi lila terusing batin.(W.J.S Poerwadarminta) sedangkan dalam kultur Madura yaitu exhlas.(Iqbal Nurul Azhar). Dari beberapa contoh tersebut secara umum ikhlas dapat diartikan sebagai sebuah pelepasan emosi negaitf dari dalam jiwa manusia sehingga memiliki sikap tulus dan menerima.(G. Corey)

\section{Berbaik Sangka}

Dalam Al-Quran terdapat beberapa aspek yang memerintahkan kita sebagai umat muslim untuk berbaik sangka (husnudzdzon), seperti yang dijelaskan pada surat Al-Hujurat 12 " $\mathrm{Hai}$ orang-orang yang beriman, jauhilah kebanyakan berburuk sangka (kecurigaan), karena sebagian dari berburuk sangka itu dosa"

Secara etimologi husnudzdzon berasal dari dua kata bahasa Arab, husn yaitu baik dan az-zan dapat diartikan sangka atau prasangka. Maka arti keseluruhan dari husnudzon sendiri yaitu berbaik sangka. Husnudzon menjadi suatu landasan untuk manusia agar selalu berfiki positif atas segala peristiwa yang telah dan akan dialami. Terdapat dua model pengaplikasian husnudzon ini yaitu husnudzon kepada Allah dan kepada manusia.(Satrio Pinandito) Husnodzon kepada Allah berbaik sangka atas segala sesuatu yang diberikan oleh-Nya. Dalam hadis qudsi Syaikhani dan Turmudzi dari Abu Huraurah r.a " 
Jurnal Inteligensia, Volume 7, No. 2, September 2019

Aku tergantung kepada prasangka hamba-Ku". Terkadang kita sebagai manusia ciptaan-Nya selalu mengeluh tentang harapan yang tidak sesui dengan kenyataan, tentang do'a yang tidak kujung terkabulkan. Pemikiran tersebut malah akan menjauhkan diri kita kepada Sang Maha Pencipta. Seharusnya kita lebih bijaksana dalam menanggapi permasalahan dengan berfikiran bahwa ada hal yang lebih baik lagi bagi kita. Dalam Surat AlBaqarah 216, "Boleh jadi kamu membenci sesuatu padahal ia amat baik bagimu, dan boleh jadi (pula) kamu menyukai sesuatu, padahal ia amat buruk bagimu; Allah mengetahui, sedangkan kamu tidak mengetahui".

Kedua husnudzon kepada sesama manusia. Husnudzon atau berbaik sangka terhadap sesama manusia merupakan hal yang sangat penting harus kita miliki. Penelitian yang dilakukan Amanda \& Mardito menjelaskan bahwa terdapat korelasi yang signifikan antara prasangka masyarakat terhadap muslimah bercadar dengan jarak sosial.(Resti Amanda). Ini memuktikan bahwa prasangka berengaruh sangat signifikan terhaap hubungan baik antar manusia, seperti contoh pemicu dan pe- edam konflik. (Muhammad Afandi)

\section{Silaturohim}

Dalam Al-Quran terdapat beberapa aspek yang memerinahkan kita sebagai umat muslim untuk saling bersilaturohim, seerti yang dijelaskan pada Surat An-Nisa 1, Muhammad 22:

" Maka Apakah kiranya jika kamu berkuasa kamu akan membuat kerusakan di muka bumi dan memutuskan hubungan kekeluargaan?"

Hai sekalian manusia, bertakwalah kepada Tuhan-mu yang telah menciptakan kamu dari seorang diri, dan dari padanya Allah menciptakan isteinya; dan dari pada keduanya Allah memperkembang biakkan laki-laki dan perempuan yang banyak. dan bertakwalah kepada Allah yang dengan (mempergunakan) nama-Nya kamu saling meminta satu sama lain, dan (peliharalah) hubungan silaurrahim. Sesungguhnya Allah selalu menjaga dan mengawasi kamu."

Kalimat silaturahim sendiri berasal dari Arab yang tersusun dari dua kosakata, shilah yaitu menyambung dan rahim berarti wanita. Jadi arti dari silaturahim itu sendiri adalah menyambung hubungan dengan kerabat. 
Jurnal Inteligensia, Volume 7, No. 2, September 2019

Selain bermakna menyambung hubungan kekerabatan, silaturahim juga memiliki arti yang berbeda ketika kalimatnya diubah menjadi silaturahmi. Perbedaan itu terletak pada kalimat rahim diubah menjadi rahmi yang berarti kasih sayang 'arrahm'. Maka ketika kita menggunakan kalimat silaturahmi pemaknaannya lebih luars yaitu menjalin hubungan kasih sayang dengan saudara seiman, dari pada silaturahim yang bermakna hanya terbatas menjalin hubungan dengan saudara sedarah.(Muhammad Habibillah) Kedua kalimat tersebut memiliki makna yang sama tergantung bagaimana niat manusia itu sendiri, karena pada hakikatnya manusia diperintahkan oleh Allah untuk menjalin hubungan kasih sayang terhadap manusia di sekitarnya. Sesuai perintah Allah dalam surat Maryam 96 " Sesungguhnya orang-orang yang beriman dan beramal sholeh, yang Maha Rahman (Allah SWT) akan mengadakan perasaan kasih sayang bagi sesamanya". Ketika kita pahami secara logika maka ayat tersebut memerintahkan kita sebagai semua umat Islam harus hidup berdampingan dengan menjalin kasih sayang .
Silaturahima atau silaturahmi juga dibutuhkan ketika kita sebagai makhluk sosial ingin berhubungan baik dengan manusia lainnya. Secara realita yang ada silaturahmi ini dibutuhkan agar dapat mendekatkan yang jauh dan mengikat yang tidak terikat. Yang dimaksut mendekatkan yang jauh yaitu dengan silaturahmi akan timbul lebih keakraban antara individu manusia dengan manusia lainnya, sedangkan mengikat yang tidak terikat ialah ketika invidu manusia belum saling mengenal dengan silaturahmi akan saling mengenal, bahkan akan menjadi saudara. Oleh karena itu, manfaat silaturahmi tidak dapat diragukan lagi memiliki kelebihan yang nyata agar hubungan baik dengan manusia lainnya menjadi lebih efektif. Dalam salah satu hadist Rosulullah juga menyebutkan keutamaan silaturahmi bukan hanya untuk berhubungan baik saja, tetapi dengan silaturahmi manusia akan dilapangkan rizki dan panjang umur. Penjelasan itu sebagaimana dalam hadist Rosululah, dari Ibnu Syihab, dari Annas bin Malik berkata bahwa sesungguhnya Rasulullah saw bersabda: barang siapa ingin dilapangkan rizkinya dan ditangguhkan atau dipanjangkan umurnya, maka hen- 
daklah dia menyambung tali kasih dengan keluarganya.(H.R. Bukhori Muslim). Secara logika hadist tersebut memiliki hubungan yang sangat signifikan karena dengan silaturahmi realasi bisnis kita akan bertambah sehingga terbuka peluang-peluang bisnis dan informasi yang lebih banyak.

\section{Penutup}

Dari analisis literatur di atas maka ditemukan kesimpulan yang rasional bahwa kecerdasan sosial yang dikeluarkan oleh Daniel Goleman secara definisi merupakan ilmu yang menerangkan konsep bagaimana manusia berhubungan baik dengan manusia lainnya, dalam Islam juga mengajarkan ilmu berhubungan baik antara manusia satu dengan manusia lainnya akan tetapi ilmu kecerdasan sosial Islam ini tidak terlepas dari Hablumminallah (hubungan manusia dengan Allah SWT sang pencipta). Hal ini dapat dilihat ketika kecerdasan sosial yang dicetuskan oleh
Daniel Goleman proses pemerolehannya hanya berdasarkan manusia sebagai objek penelitiannya, sedangkan ilmu Islam lebih menitik beratkan kepada Al-Quran dan Hadis sebagai pegangan ilmu paling dasar dan utama yang semua itu bukan hanya objek penelitiannya bersifat horizontal saja (Hablum Minannas) akan tetapi tidak terlepas dari kajian vertikal (Hablum Minallah). Seperti contoh indikator Ikhlas pada kajian diatas yang merupakan salah satu indikator manusia berhubungan baik dengan manusia lainnya. Indikator Ikhlas ini bukanlah sebuah tindakan manusia yang dapat dilihat oleh verbal ataupun nonverbal, akan tetapi orang yang melakukan tindakan Ikhlas karen Allah SWT tidak akan memberitahukan kepada orang lain. Indikator iklas ini yang akan melandasi berabgai tindakan seperti tolong menolong, menghargai, bekerjasama, dan segala tindakan yang melibatkan kemanusiaan. 


\section{PUSTAKA ACUAN}

Afandi, Muhammad. 2013. Prasangka: Potensi Pemicu Konflik Internal Umat Islam. Jurnal Penelitian Sosial Keagamaan, Vo. 26 No. 2 Hal. 113-140.

Akbar, Wishnugroho. 2018. BIN Ungkap 39 Persen Mahasiswa Terpapar Radikalisme.

https://www.cnnindonesia.com/nasional/20180429023027-20-

294442/bin-ungkap-39-persen-mahasiswa-terpapar-radikalisme.

Diakses, 03-01-2019, 10.40.

Amanda, Resti \& Mardianto. 2011. Hubungan Antara Prasangka Masyarakat Terhadap Muslimah Bercadar dengan Jarak Sosial. Jurnal RAP UNP, Vol 5 No. 1, Mei 2014 hal 72-81.

Ausop, Zaenal Asep. 2014. Islamic Character Building, Membangun

Insan Kamil, Cendikia Berakhlak Qur'an. PT Grafindo Media Pratama.

Azhar, Iqbal Nurul. 2010. Jejak Protobahasa Austronesia Pada Bahasa Madura (Kajian Bandingan Historis terhadap Retensi dan Inovasi Fonem Protobahasa Austrinesia pada Bahasa Madura). Jurna Metalingua, Vol. 8 No. 1, Juni 2010.

Corey, G. 2005. Theory and Practice of Counseling and Psychotherapy 7th edition. Belmont: Books/Cole- Thomson learning.

Goleman, Daniel. 2015.Kecerdasan Sosial: Ilmu Baru Tentang Hubungan Antar Manusia. Cetakan Kedua. Diterjemahakan oleh: Harionao S. Imam. Jakarta: PT Gramedia Pustaka Utama.

Habibillah, Muhammad. 2013. Raih Berkah Harta dengan Sedekah dan Silaturahmi. Cetakan 1. Yogyakarta: Sabil.

Hergenhanhn B.R \& Matthew H. Olson. 2008. Theories of Learning. Jakarta: Prenada Media Group.

Hoeer, Thomas R. 2007. Buku Kerja Multiple Intellegences: Pengalaman New City School di St. Louis, Missouri, As, Dalam Menghargai Aneka Kecerdasan Anak. Cetakan kesatu. Diterjemahkan: Ary Nilandari. Bandung: Mizan Media Utama.

Karlina, Supelli. 2011. Dari Kosmologi ke Dialog: Mengenal Batas

Pengetahuan, Menentang Fanatisme. JakartaLMizan.

Kartono, Kartini. 2011. Patologi Sosial 2 Kenakalan Remaja. Jakarta:

Rajawali Pers. 
Jurnal Inteligensia, Volume 7, No. 2, September 2019

Marzuki. 2009. Pembinaan Akhlak Mulia Dalam Berhubungan Antar Sesama Manusia Dalam Perspektif Islam. Jurnal Humaika, Vol. 9 No. 1 Hal. 25-38.

Nata, Abuddin. 2018. Psikologi Pendidikan Islam. Depok: Raja Grafindo Persada.

Pinandito, Satrio. 2011. Husnuzan dan Sabar Kunci Sukses Meraih Kebahagiaan Hidup Kiat-Kiat Praktis Berfikir Positif Menyiasati Persoalan Hidup". Jakarta: PT Elex Media Komputindo. Poerwadarmita, W.J.S. 1939. Baoesastra Djawa. Batavia: J.B.Wolters. Suryabrata, Sumadi. 2004. Psikologi Pendidikan. Jakarta: Raja Grafindo Persada.

Yudiani, Ema. 2013. Dinamika Jiwa Dalam Perspektif Psikologi Islam. Jurnal Ilmu Agama Raden Fatah, No.1/ 45-59. 